\title{
The Urban Transformation with New Legal Regulations
}

\author{
Fatih TAKTAK $^{1}$, Mahir Serhan TEMIZ ${ }^{1}$ \\ ${ }^{1}$ Usak University, Faculty of Engineering, Geomatics Engineering Department,
}

\section{Article Info}

Article history:

Received June $01^{\text {th }}, 2017$

Revised June $16^{\text {th }}, 2017$

Accepted June $17^{\text {th }}, 2017$

\section{Keyword:}

Urban Transformation

Trents Analysis

Historical Development

Turkey

TOKI

\begin{abstract}
All around the world, cities need projects and applications for renewal, transformation, resettlement and improvement due to reasons such as economic reasons, inadequacy in social development, excessive population accumulation, wrong place selection and natural disasters. Many project application examples are available in the world and in our country. They vary in their purpose, form of implementation, organizational patterns and outcomes. In the process of reclaiming troubled areas of cities; a spatial transformation is also being studied at the same time to ensure the social and cultural development.

In this context, the process of urban transformation in our country has been evaluated from the perspective of new legal regulations. In the study, firstly, the urban transformation was very briefly defined and it was focused on the historical development of urban transformation in the Turkey and world. Secondly, Past legal regulations and current legal regulations regard to urban transformation were examined. Lastly, the new legislation was critically discussed. Also the current trends related to urban transformation are investigated.
\end{abstract}

\section{Corresponding Author:}

Fatih Taktak,

Departement of Geomatics Engineering,

UsakUniversity,

Ankara-İzmir Road 8. km, 1Eylul Campus,Usak/Turkey

Email: fatih.taktak@usak.edu.tr

\section{Introduction}

The urban transformation is the creation of a viable road map as a result of examining the economic, social and spatial characteristics of a region, taking into account urban problems and needs. Urban transformation is a human-focused practice [1]. The aim of urban transformation is to create cities in livable standards. Many problems are encountered in urban transformation applications [2]. These could be the problems arising from the inability to create the corporate structure, problems arising from local governments, lack of staff with sufficient knowledge about the subject, problems caused by the lack of legislation, unsuccessful location selection, issues encountered in informing the projects and financing problem etc., Therefore, in order to ensure rapid and healthy progress of urban transformation, the application regulationwas revised [3], [4].

While trying to sustain intense work agenda in the country, the government took action to remove the obstacle to investors and the regulation on urban transformation was changed [5]. The Council of Ministers will be commissioned to declare a particular area as a 'risky area'. Thus the contractorwill be facilitated by Project developments designed for large areas. If 65 percent of a region is at risk, 100 percent will be covered. In this respect, the objection of individual building owners can be avoided.so that the project will be accelerated. Urban transformation will also be possible in the immovables falling within the scope of the Cultural and Natural Assets Law [6],[7]. 


\section{Material and methods}

\subsection{The Trends Analysis}

Developing data source is internet search queries [8]. Daily, large numbers of users around the world search information via Web search engines. The internet search engine Google provides an internet service, Google Trends (GT), for all internet users to browse the volume of search queries. GT analyzes a fraction of Google web searches to compute how many searches have been done for the terms that users enter, relative to the total number of searches done on Google over time [9]. It is reasonable that some GT regarding specific economic issues can demonstrate the dynamic situation of internet economic-seeking behaviors [10], [11], [12].

GT provides a time series index of the volume of queries which users enter into Google in a given geographic area [13]. The query index is based on query share: the total query volume for the search term in question within a particular geographic region divided by the total number of queries in that region during the time period being examined [14], [15]. The maximum query share in the time period specified is normalised to be 100 , and the query share at the initial date being examined is normalised to be zero [16],[17]. The Google data are not given in absolute volumes but are indexed to the highest observed search volume, which is set to 100 . Consequently, it is not possible to ascertain the frequency of searches that took place at any given time, but only how the searches have changed over time [18], [19].

In this study, the current trends related to urban transformation are investigated. Most relevant trends have been identified. A comparison chart has been obtained with the help of the google trends program. Comparative expressions are given in the graphic. As it can see in the graphic, the most searched phrasewithin one year has been "Housing Development Administration (TOKI)". The lowest call within one year in these trends is the "urban transformation credit" statement. It is understood from the graph, the institution that makes the urban transformation comes to the forefront.

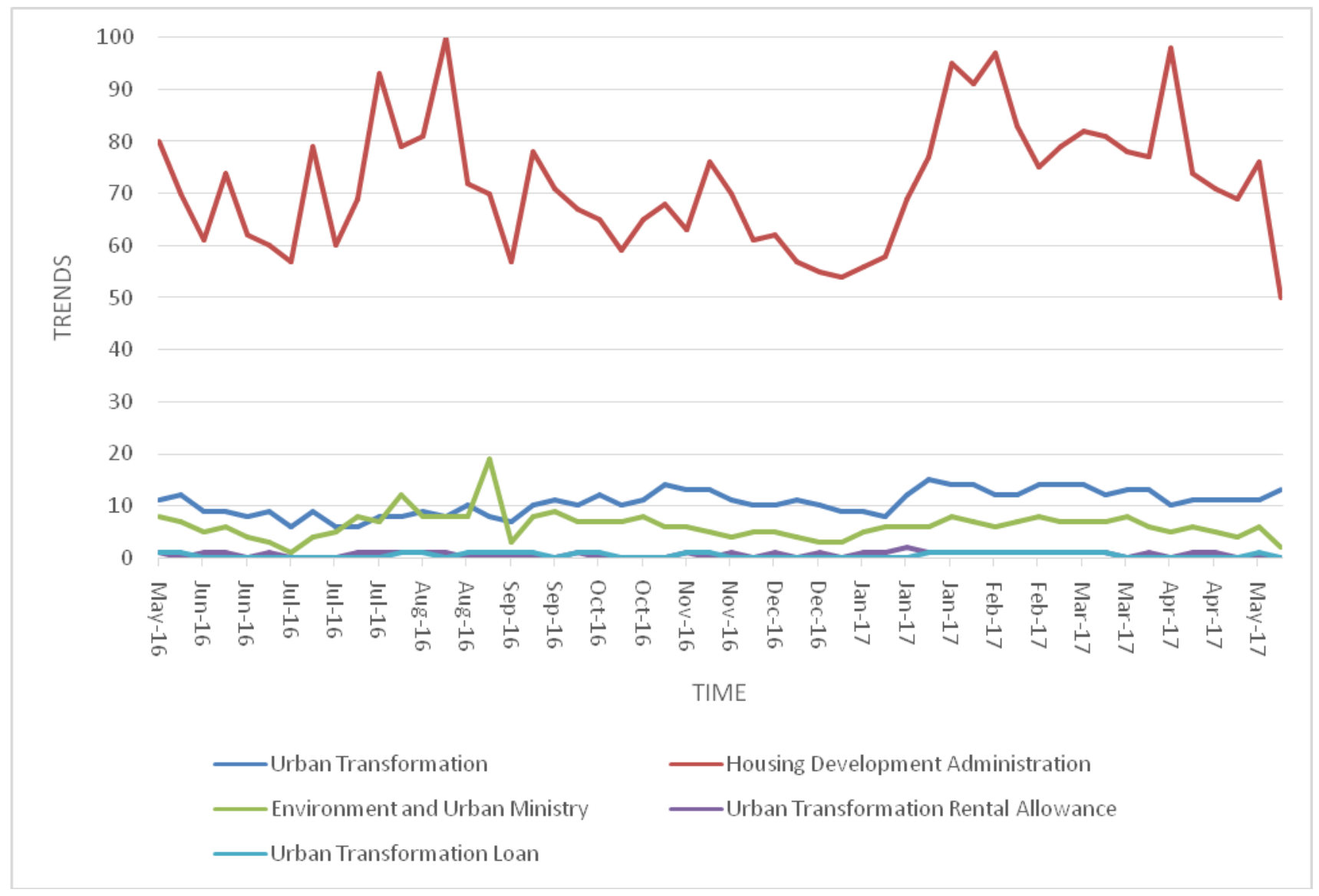

Figure 1. Five trends related to urban transformation are listed. 


\subsection{The Historical Development of Urban Transformation}

Urban transformation applications first appeared in the 19th century as the urban growth movements that took place in Europe, some parts of which have been demolished and reconstructed (urban renewal) [20], [21]. Over time, the political and economic structure of the process of urban transformation has also changed the process of urban planning, from national development towards global integration [22]. For this reason, it is said that the urban transformation applications in the world have different approaches to different periods. Urbanization movements was started in republican period in the country. In the 1950s urbanization was accelerated due to the immigration to the city from the countryside. As the cities are not ready for this situation, the seeds of unhealthy urbanization have been thrown. While the industrial sector was on the rise, there was a decline in the agricultural sector. For this reason, urban spaces need to be transformed and renewed. Almost every province in our country has places that lack technical infrastructure and other equipment that do not conform to regular urban development.

Due to such matters, regular legal regulations have been made. From past to present, the legal regulations related to urban transformation are stated in table1 [23].

Table 1. Legislation Regarding Urban Renewal in the Past to Today.

\section{Legislation Regarding Urban Renewal in the Past to Today}

\begin{tabular}{|c|c|c|}
\hline $\begin{array}{l}\text { Law No } \\
\text { Date }\end{array}$ & Law Name & Purpose \\
\hline $\begin{array}{l}\text { Law No:7367 } \\
\text { July 21, } 1959\end{array}$ & $\begin{array}{l}\text { Law on Land and Ares from } \\
\text { Transferable to } \\
\text { Municipalities }\end{array}$ & $\begin{array}{l}\text { The main purpose of the law are to use these land for the production of urban land and Free } \\
\text { transfer to municipalities of State-owned land. By law, Law No. 6188, the state-owned lands } \\
\text { and the transfer-related provisions of the other related lands are abolished. }\end{array}$ \\
\hline $\begin{array}{l}\text { Law No:634 } \\
\text { June 23, } 1965\end{array}$ & Floor Ownership Law & $\begin{array}{l}\text { Independent property rights may be established by the owners or joint owners of the real estate } \\
\text { on the basis of the provisions of this Act on the completed buildings, apartments, business } \\
\text { offices, shops, warehouses, warehouses, etc. which are individually and individually available. } \\
\text { Easement rights may be established in accordance with the provisions of this Law by the land } \\
\text { owners or joint owners of the land on the basis of the property of the floor which will be } \\
\text { overcome after the construction is completed. }\end{array}$ \\
\hline $\begin{array}{l}\text { Law No:775 } \\
\text { July 20, } 1966\end{array}$ & Slums Act & $\begin{array}{l}\text { Refurbishment of existing slums, liquidation, preventing the re-construction of squatter and the } \\
\text { provisions of this Law shall apply to the measures to be taken for these purposes }\end{array}$ \\
\hline $\begin{array}{l}\text { Law No:1164 } \\
\text { April 29, } 1969\end{array}$ & $\begin{array}{l}\text { Land Production and about } \\
\text { the Law }\end{array}$ & $\begin{array}{l}\text { Purpose of this Law; Buying and selling to prevent excessive price increases of the Land; } \\
\text { Housing, industry, education, health and tourism investments and public facilities. }\end{array}$ \\
\hline $\begin{array}{l}\text { Law No:2985 } \\
\text { March 02, } 1984\end{array}$ & Mass Housing Law & $\begin{array}{l}\text { Meeting the housing needs, arranging the procedures and principles that will be applied to those } \\
\text { who build houses, development of industrial construction techniques and tools and equipment } \\
\text { suitable for the materials of the country and support be made by the State. It is subject to the } \\
\text { provisions of this Law. }\end{array}$ \\
\hline $\begin{array}{l}\text { Law No:2981 } \\
\text { Feb. 24, } 1984\end{array}$ & Zoning amnesty law & $\begin{array}{l}\text { Purpose of this Law; Arrangements to be implemented in respect of all buildings constructed in } \\
\text { contradiction to the legislation of Zoning and shantytown and determine the principles of } \\
\text { application, determination, evaluation, implementation and announcement of these transactions } \\
\text { and other relevant matters. }\end{array}$ \\
\hline $\begin{array}{l}\text { Law No:3194 } \\
\text { May 03, } 1985\end{array}$ & Zoning law & $\begin{array}{l}\text { This law is designed to provide settlement places and structures of these places in accordance } \\
\text { with plan, science, health and environmental conditions }\end{array}$ \\
\hline $\begin{array}{l}\text { Law No:5104 } \\
\text { March 04, } 2004\end{array}$ & $\begin{array}{l}\text { North Ankara Entrance } \\
\text { Urban Transformation Project } \\
\text { Law }\end{array}$ & $\begin{array}{l}\text { Purpose of this Law; North Ankara entrance and surrounding areas is to create a project of } \\
\text { urban transformation. So; the development of physical condition and environmental view in } \\
\text { Ankara, beautification, provision of a healthy settlement system and increase the level of urban } \\
\text { life. }\end{array}$ \\
\hline $\begin{array}{l}\text { Law No:5216 } \\
\text { July 10, } 2004\end{array}$ & $\begin{array}{l}\text { Metropolitan Municipality } \\
\text { Law }\end{array}$ & $\begin{array}{l}\text { The purpose of this law is to regulated the legal status of the administration of the metropolitan } \\
\text { municipality and to ensured efficient, efficient and harmonious implementation of the services }\end{array}$ \\
\hline $\begin{array}{l}\text { Law No:5226 } \\
\text { July 14, } 2004\end{array}$ & $\begin{array}{l}\text { Conservation of Cultural and } \\
\text { Natural Assets }\end{array}$ & Cultural and Natural Heritage Protection Act was amended to certain reagents. \\
\hline $\begin{array}{l}\text { Law No:5273 } \\
\text { Dec. 08, } 2004\end{array}$ & $\begin{array}{l}\text { Law on the Removal of the } \\
\text { General Directorate of the } \\
\text { Land Office }\end{array}$ & The General Directorate of Land Office was removed together with the organization. \\
\hline $\begin{array}{l}\text { Law No:5302 } \\
\text { Feb. 22, } 2005\end{array}$ & $\begin{array}{l}\text { Special Provincial } \\
\text { Administration Law }\end{array}$ & $\begin{array}{l}\text { Purpose of this Law is to regulate the establishment, Organs, management, duties, powers and } \\
\text { responsibilities and working principles and principles of Special provincial administration }\end{array}$ \\
\hline $\begin{array}{l}\text { Law No:5393 } \\
\text { July 03, } 2005\end{array}$ & Municipal Law & $\begin{array}{l}\text { The purpose of this law is to regulate the procedures and principles of the establishment, the } \\
\text { organs, the administration, the duties, authorities and responsibilities of the municipality. }\end{array}$ \\
\hline $\begin{array}{l}\text { Law No:5998 } \\
\text { June 17, } 2010\end{array}$ & $\begin{array}{l}\text { Law Amending the Law on } \\
\text { Municipalities }\end{array}$ & $\begin{array}{l}\text { Municipality, with the decision of the municipal council can apply urban renewal and } \\
\text { development projects that to create residential areas, industrial areas, commercial areas, } \\
\text { technology parks, public service areas, recreational areas and all kinds of social facilities areas, } \\
\text { rebuilding and restoring old parts of the city, in order to protect the historical and cultural }\end{array}$ \\
\hline
\end{tabular}


Law No:6306 Law on Converting of Areas

May 16, 2012 Under Disaster Risk

Law No:6360

Dec. 06, 2012

Law No:6360

Nov. 12, 2012

Law No:6306

Oct. 27, 2016 thirteen provinces also and with Twenty-Six County establishment, Law on the Amendment of Decrees on Certain Laws and Laws

fourteen provinces also and with Twenty-seven County establishment, Law on the Amendment of Decrees on Certain Laws and Laws

Regulation of Law on Converting of Areas Under Disaster Risk
Purpose of this Law, In areas where there are risky structures outside these areas with areas under disaster risk is to determine the principles and procedures for improvement, liquidation and renewal in order to constitute healthy and safe living environments in accordance with science and art norms and standards.

The metropolitan municipality was established with the same name as the provincial property boundaries in Aydın, Balıkesir, Denizli, Hatay, Malatya, Manisa, Kahramanmaraş, Mardin, Muğla, Tekirdağ, Trabzon, Şanlıurfa and Van and these municipalities' municipalities have been transformed into the metropolitan municipality.

Law No. 6360, adopted on 12 November 2012 was amended on 06 December 2012; Ten Fourteen Metropolitan Municipalities and the Establishment of the Twenty-Seven Districts Some Law and the Law on the Amendment of the Decrees in the Law has become law.

Due to the size of the problems experienced during the urban transformation process, it can be seen that there are almost serious and process-accelerating changes in the regulation and an urban transformation process almost at the jet speed.

\subsection{Online Submission Change of Urban Transformation Regulatıon and Improvements}

1. If a deterioration occurs in $65 \%$ of one or more of these criteria, these regions can now be declared as Risky Areas, in the areas where infrastructure and superstructure have been damaged, contrary to the zoning legislation, inadequate planning and infrastructure services, in order to avoid the cancellation of the Council of State in risky areas.

2. The section regarding the need to be at least $15.000 \mathrm{~m}^{2}$ in risky area advertising has been removed from the obligation. Thus, without any limitation of $\mathrm{m}^{2}$, the risky areaadvertising in each region can be declared provided that it carries other criteria.

3. The personnel who will work in establishments that will determine risky structures are entitled to issue certificates in the institutions and organizations that will be determined by the Ministry for the necessity of obtaining certificates from the Ministry of Environment and Urbanization. The certificate exemption granted to universities is limited to academic staff only. At least one civil engineer will operated in the licensed institutions that will perform risky structure detection.

4. The principles for risky structure determination are clarified and will be used for buildings and structures for people to sit, work, play or rest or worship, and structures for the protection of animals and their property. Buildings that are under construction and that are not resident, damaged or unstable due to deformation or static will not be subject to risky structure determination.

5. To be in risky structure determination application; Petition, identity photocopy and current title deeds status certificate will be required. Land register is not enough with the old state. The current title deeds status document must be obtained from the relevant place and submitted to the licensed company.

6. The big problem in the courts has been resolved in the owner's dead real estate. In the apartments that are trying to get along with the requests for intervention, a very big problem has been solved by granting the authority to assign a seatkeeper to the Ministry.

7. In the immovables falling within the scope of the Culture and Natural Assets Law, the application of urban transformation will now be possible. Here, the owner or one of the owners of the building will be present and after the risky structure is determined, the application will be decided with the decision to be taken from the establishment.

8. Evictions which are not made to tenants and limited beneficiaries are no longer valid. The tenant or limited rights owner must be notified about the evacuation periods of municipalities. If this is not done in the previous regulation, which is not sanctioned, the periods will not start. So if you have a tenant, you should give him a notary etc. by roads. If you have not sent a notice of eviction, the time will be restarted by the municipality.

At the end of the evacuation periods, electricity, water and natural gas services have to be stopped. No municipalities will not be able to refrain from writing this article again: I will not do any electricity, water or gas administration process. 
9. With regard to buildings that have not been demolished at the end of the current evacuation periods, the expectation of the agreement of the owners is now completely abolished.2 month audits shall be carried out and the buildings which are not demolished shall be demolished by law enforcement support and civilian authority due to Disaster Relief.The situation in the previous regulation gave rise to months and years of elongation due to the fact that no agreement was reached with $2 / 3$ of apartments or sites.The building which can no longer be demolished by supervision made in buildings or blocks shall be immediately demolished by the administration.

10. At risky areas or risky structures, decisions can be made by $2 / 3$ without destroying the structure. Again with the decision of $2 / 3$ before the structure was destroyed; It will be allowed to The zoning application in zoning island.

11. Blocked structures existing in a parcel are separated from structures that have not been identified as risky structures. A commentary will be put on the buildings where risky structures are determined. In practice the parcel is not over the whole, the risky structure will be decided by a majority of $2 / 3$ of the total number of building owners.

12. If the floor easement or floor ownership facilities are requested on behalf of the rights owners; It may be made by the Ministry, TOKI or Administration. In this case, Independent section on the rights owners should definitely be shown in the project.

13. The requirement that the building is now demolished has been removed in order to sell a $1 / 3$ share of the land which is not included in the decision with $2 / 3$.So that making decision with $2 / 3$ and submitting 15-day warning notice to those who do not participate in the meeting has been made sufficient.One of the biggest problems in urban transformation has thus been solved.Due to the evacuation distress and contractor's obligation to pay rent, A solution has been found to delay the demolition request.An auction sale will be possible without demolition.

14. After sales with auction, Cancellation of contract or contract documents, resale, That is, the process of prolonging the sale by repeating the sale; It is completely closed.Accordingly, the land owner who declares that he will sign the contract by participating in the tender; If you cancel any of the contract or its annexes after signing the contract, you will be sold to the highest bidder in the 90-day period and to the others in turn if you do not accept it.In this case, the sale has been turned into a single transaction and the possibility of second or third sales has ceased.

15. Rental allowance is determined as 36 months in risky areas, 18 months at risky structures. By changing the previously restricted state; the owners, tenants or limited rights holders can be given rental allowance for all the structures that they have or have fallen under the law. The rent allowance will be accepted as valid if it is requested within 1 year from the date of evacuation.

16. The tax fees and fee exemption paid to the municipalities have been removed. Municipalities will continue to charge fees [24].

\section{Conclusions}

Unplanned or contrary to the provisions of the plan,constructionsare the biggest obstacles in front of the regular, healthy and aesthetic urbanization. The struggle with the illegal structures is one of the basic tasks of the administration. Due to the weaknesses and hesitations that arise in the struggle against illegal construction,Infrastructures and superstructure have led to the emergence of problematic cities.It is inevitable that cities that are unplanned, irregular and irregularly structured can not fulfill the expected function of themselves, but also cause risks in the safety of life and property of the people who live there.In the practice of urban transformation and in the struggle against disaster risk, the administration has the power to directly influence and create pressure on rights and freedoms. It should be essential to be moderate in the use of the authority recognized by the competent authority.If it is possible to transform without ending the property right, the practice must be carried out in this framework.The process of urban transformation should be as short as possible. The amendment of the regulation is also aimed for this purpose. It is considered necessary to create a sustainable urban model with the participation of the transformation projects, all other institutions and public. Implementation strategies must be defined before the transformation process begins.

Rather than creating irresponsibility chains through piecemeal regulation, solutions must be produced under a single set of laws; and socio-economic and development plans must be displayed on terms to be addressed seriously. In addition, the new legal regulations have not yet fully resolved the ownership problems. There is 
still a problem in the implementation of urban transformation and a need to reorganize property rights.It should not be forgotten that the main purpose is to increase the quality of life. They are missing in our laws and should be supported by new legal regulations.

In this study, firstly, terms related to the general trend in the country's urban transformation were compared among themselves. The "TOKI (Housing Development Administration )" term that stands out among the terms was determined by the google trends program. Then the issue of urban transformation, legal and application dimensions were discussed in general terms. In the last part of the study, the legal grounds related to urban transformation and the criticisms directed to the practices were emphasized.

\section{References}

[1] Montgomery, M. R., "The urban transformation of the developing world," science, 319(5864), 761-764, 2008.

[2] Tasan-Kok, T., "Analysing Path Dependence to Understand Divergence: Investigating Hybrid NeoLiberal Urban Transformation Processes in Turkey," European Planning Studies, vol. 23, no. 11, 02 Nov. 2015, p. 2184-2209, 2015.

[3] Tas, N. and Tas, M., "Determining of the Local Housing Identity in Urban Transformation Areas under Disaster Risk: Bursa, Turkey." Natural Hazards, vol. 75, no. 1, n.d., pp. 119-139, 2017.

[4] Demirli, M., Ultav, Z., and Demirtas-Milz, N., "A socio-spatial analysis of urban transformation at a neighborhood scale: The case of the relocation of Kadifekale inhabitants to TOKI Uzundere in Izmir", Cities, 48, pp. 140-159, 2017.

[5] Cahantimur, A., Ozturk, R., and Ozturk, A., "Securing land for urban transformation through sustainable brownfield regeneration - the case of Eskisehir, Turkey." Environment And Urbanization 22, no. 1 (n.d.): 241-258, 2010.

[6] Çağla, H. and Inam Ş., "Yerel Yönetimler Öncülüğünde Yapılan Kentsel Yenilenme Proje Uygulamaları Üzerine Bir İnceleme", TMMBO Harita ve Kadastro Mühendisleri Odası, 12. Türkiye Harita Bilimsel ve Teknik Kurultayı, 11-15 Mayıs, Ankara, 2009.

[7] Ayhan, F., "Kentsel Dönüşüm Hukuku (Kentsel Dönüşüm Kavramı Ve Tarihsel Gelişimi)," İstanbul Üniversitesi S.S.ONAR İdare Hukuku ve İlimleri Araştırma ve Uygulama Merkezi Yayınları, s: 87, 2013.

[8] Choi, H., and Varian, H. "Predicting the present with Google Trends." Economic Record 88. s1: 2-9, 2012.

[9] Carriere-Swallow, Y. and Labbe F., "Nowcasting with google trends in an emerging market." Journal of Forecasting, DOI:10.1002/for.1252, 2011.

[10] Valdivia, A. and Monge-Corella, S., "Diseases tracked by using Google trends, Spain,". Emerg Infect Dis, 16(1), 168, 2010.

[11] Troumbis, A.Y., "Declining Google Trends of public interest in biodiversity: semantics, statistics or traceability of changing priorities?," Biodiversity And Conservation: 1-11, 2017.

[12] Pelat, C., Turbelin, C., Bar-Hen, A., Flahault, A., and Valleron, A. J., "More diseases tracked by using Google Trends." Emerging infectious diseases 15.8: 1327-8, 2009.

[13] Carrière-Swallow, Y., and Labbé, F., "Nowcasting with Google Trends in an emerging market." Journal of Forecasting 32.4: 289-298, 2013.

[14] Kristoufek, L., " Can Google Trends search queries contribute to risk diversification? " ArXiv önizleme arXiv: 1310.1444, 2013.

[15] Valdivia, A., and Monge-Corella, S., "Diseases tracked by using Google trends, Spain." Emerg Infect Dis 16.1: 168, 2010.

[16] Zhou, X., Ye, J. and Feng, Y., "Tuberculosis surveillance by analyzing Google trends." IEEE Transactions on Biomedical Engineering 58.8: 2247-2254, 2011.

[17] Yılmaz, H. H., Yazıhan, N., Tunca, D., Sevinç, A., Olcayto, E. Ö., Özgül, N., and Tuncer, M., "Cancer trends and incidence and mortality patterns in Turkey." Japanese journal of clinical oncology 41.1: 10$16,2011$. 
[18] Esbah, H., "Land use trends during rapid urbanization of the city of Aydin, Turkey." Environmental Management 39.4: 443-459, 2007.

[19] Chadwick, M. G., and Sengül, G., "Nowcasting the Unemployment Rate in Turkey: Let's Ask Google." Central Bank Review 15.3: 15, 2015.

[20] Geymen, A.,"On the Use of Terrestrial Laser Scanners to Facilitate Project Studies of Urban Transformation in the Historic Peninsula of the Metropolitan Area of Istanbul." Lasers In Engineering (Old City Publishing) 20, no. 3/4: 225-239, 2010.

[21] Güzey, Ö., "The Last Round in Restructuring the City: Urban Regeneration Becomes a State Policy of Disaster Prevention in Turkey." Cities, vol. 50, 01 Feb., pp. 40-53, 2016.

[22] Ozus, E., Turk, S. S. and Dokmeci, V. "Urban Restructuring of Istanbul." European Planning Studies, vol. 19, no. 2, Feb., pp. 331-356, 2011.

[23] Kampüsü, B., "Yeni Yasal Düzenlemelerle Kentsel Dönüşüm." Planning 26.1: 51-64, 2016.

[24] Implementing Regulation of the Law No. 6306, http://www.csb.gov.tr/gm/altyapi/index.php?Sayfa=sayfa\&Tur=webmenu\&Id=295

\section{BIBLIOGRAPHY OF AUTHORS}

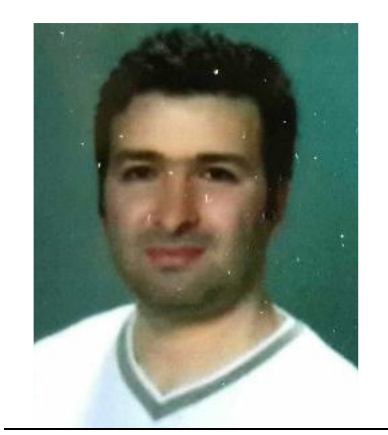

Asst. Prof. Fatih TAKTAK, born in 1978. He graduated in 1996 as Dipl.-Ing. in Geodesy and Photogrammetry Engineering at Selcuk University. He obtained his MsC degree in 2005 at Kocatepe University. He obtained his Ph.D. degree in 2013 at Yildiz Technical University. He is since 2014, Asst. Prof. of Engineering Faculty, Usak University. He is currentley working on Land Management and urban transformation.

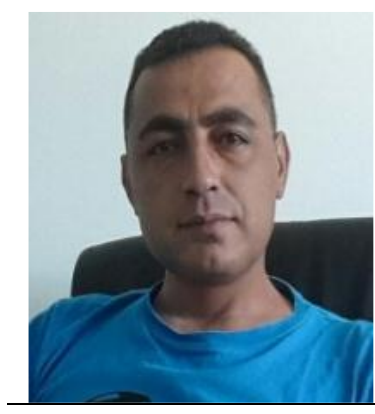

Undergraduate:Ondokuz Mayis University / 2001, Master Degree:Ondokuz Mayis University / 2005, Doctorate:Istanbul Technical University / 2012, Assistant Professor:UsakUniversity / 2003, Expertise: Photogrammetry,Image Processing 